\title{
Research Paper \\ Role of Difficulties in Emotional Regulation and Alexithymia in Prediction of Bullying
}

Reza Shabahang ${ }^{1 *}$, Seyedeh Farnaz Sedighian ${ }^{2}$, Abbas Rahimi Nezhad ${ }^{3}$, Reza Soltani Shal ${ }^{4}$

1. M.A. in General Psychology, Faculty of Psychology and Educational Sciences, University of Tehran, Iran

2. M.A. in General Psychology, Faculty of Literature and Humanities, University of Guilan, Rasht, Iran

3. Associate Professor, Department of Psychology, Faculty of Psychology and Educational Sciences, University of Tehran, Iran

4. Assistant Professor, Department of Psychology, Faculty of Literature and Humanities, University of Guilan, Rasht, Iran

Citation: Shabahang R, Sedighian SF, Rahimi Nezhad A, Soltani Shal R. Role of difficulties in emotional regulation and alexithymia in prediction of bullying. Quarterly Journal of Child Mental Health. 2019; 6(3): 40-50.

http://dx.doi.org/10.29252/jcmh.6.3.5

\section{A R T I C L E I N F O}

\section{Keywords:}

Bullying,

difficulties in emotional

regulation,

alexithymia

Received: 29 Apr 2018

Accepted: 17 Sep 2018

Available: 9 Nov 2019

\section{A B S T R A C T}

Background and Purpose: Bullying is an important and prevalent issue that can have many psychological, behavioral, cognitive, physical, economic, social, and cultural implications. In the meantime, the ability to regulate the emotions and alexithymia are among the factors influencing bullying behaviors. Therefore, the present study was carried out to investigate the role of difficulties in emotional regulation and alexithymia in predicting bullying.

Method: The research design was descriptive and correlational. The study population consisted of all first cycle secondary school students of district 2 of Rasht city in the academic year 2017-2018. The study sample included 250 students selected by convenience sampling method. Illinois Bullying Scale (Espelage \&Holt, 2001), Difficulties in Emotional Regulation Scale (Gratz \& Roemer, 2004) and the twenty-item Toronto Alexithymia Scale (Bagby et al., 1994) were used to gather of data.

Results: The results showed that non-acceptance of emotional responses $(\beta=0.21)$, difficulty engaging in goal-directed behavior $(\beta=0.43)$, impulse control difficulties $(\beta=0.70)$, lack of emotional awareness $(\beta=0.33)$, lack of emotional clarity $(\beta=0.32)$ at the significance level of 0.01 , limited access to emotion regulation strategies $(\beta=0.21)$, difficulty in identifying the feelings $(\beta=0.16)$, difficulty in describing the feelings $(\beta=0.23)$, and externally-oriented thinking $(\beta=0.24)$ at the significance level of 0.05 are able to predict bullying.

Conclusion: In sum, the results showed the relationship between bullying, difficulties in emotional regulation and alexithymia. According to findings, applying programs and methods to increase the ability to regulate emotions and reduce the mood of adolescents' alexithymia may reduce bullying behaviors which are associated with many physical and psychological disorders.

\footnotetext{
* Corresponding author: Reza Shabahang, M.A. in General Psychology, Faculty of Psychology and Educational Sciences, University of Tehran, Iran.

E-mail addresses: Reza.shabahang@ut.ac.ir
} 


\section{نقش مشكلات تنظيم هيجانى و ناكويى طبعى در ييشبينى قلدرى}

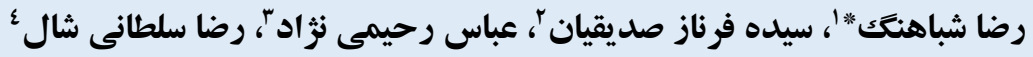

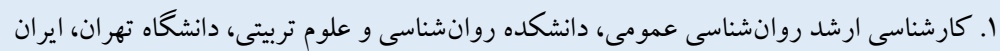

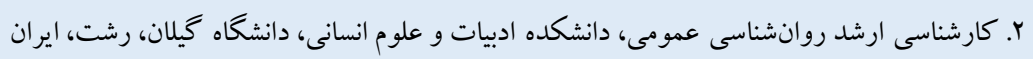

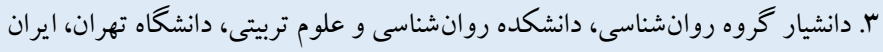

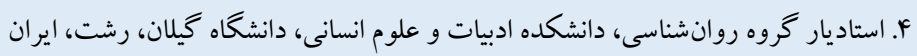

\begin{tabular}{|c|c|}
\hline جكيده & 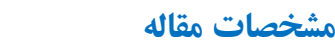 \\
\hline زمينه و هدف: قلدرى مسئلهاى مهم و شـايع است كه مىتواند بيامدهاى روانشناختى، رفتارى، شناختى، جسمانى، اقتصادى، اجتماعى، و & 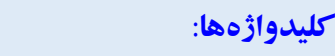 \\
\hline فرهنگى بسـيارى را در يى داشـته باشـــ. در اين بين توانايى تنظيم هيجانى و ناكويى طبعى از جمله عوامل تأثير گذار در رفتارهاى قلدرانه & 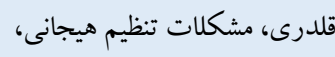 \\
\hline بهحساب مى آيند. از اين رو، بثوهش حاضر با هدف بررسى نقش مشكلات تنظيم هيجانى و ناكويى طبعى در ييشيينى قلدرى انجام شده & ناكويى طبعى \\
\hline است. & \\
\hline روش: طرح يزروهش توصيفى و از نوع همبستخى اسـت. جامعه آمارى اين يزوهش شـامل تمامى دانش آموزان مدارس متوسطه دوره اول & \\
\hline 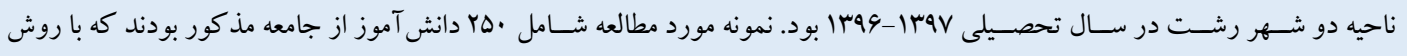 & \\
\hline 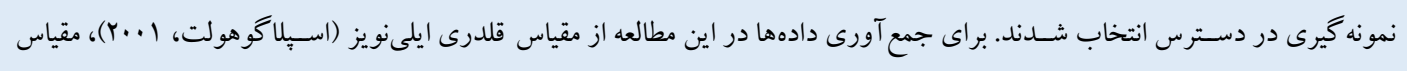 & \\
\hline 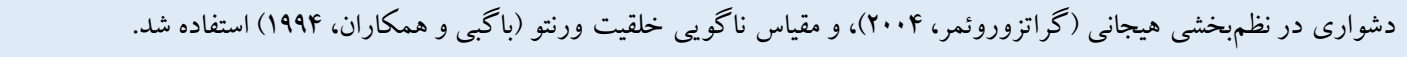 & \\
\hline 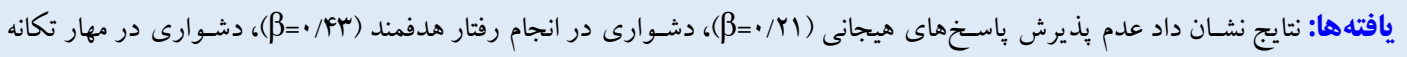 & \\
\hline 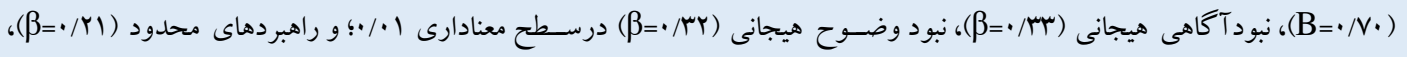 & \\
\hline 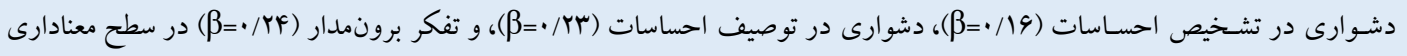 & \\
\hline 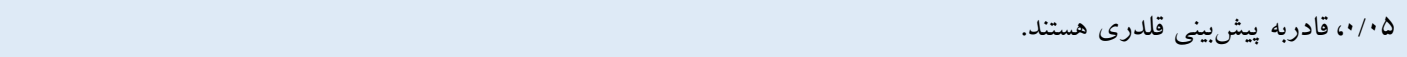 & \\
\hline نتيجــهيرى: در مجموع، نتايج به دسـت آمده حاكى از ارتباط بين قلدرى، مشــكل در تنظيم هيجانى، و ناكويى طبعى اسـت. بر طبق & 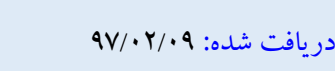 \\
\hline يـافتهـاى حاصـل از اين يُروهش مى توان با به كارگيرى برنامهها و روشهايى براى افزايش توانايى تنظيم هيجانى و كاهش ناكويى طبعى & 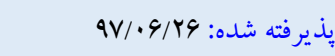 \\
\hline دانش آموزان از ميزان رفتارهاى قلدرانه آنها كه با بسيارى از اختلالات جسمانى و روانشناختى مر تبط است، بهطور معنادارى كاست. & 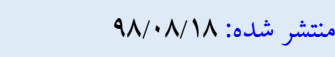 \\
\hline
\end{tabular}

* نويسنده مسئول: رضا شباهنك، كارشناسى ارشد روانشناسى عمومى، دانشكده روانشناسى و علوم تربيتى، دانشاه تهران، ايران.

Reza.shabahang@ut.ac.ir راياناهن 


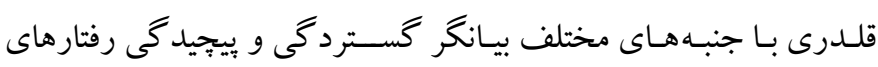
مقدمه قلدرانه و اهميت بررسى و تبيين اين دسـته از رفتارها اسـت كه مى تواند ييامدهاى منفى بسيارى رادر بيى داشته باشد.

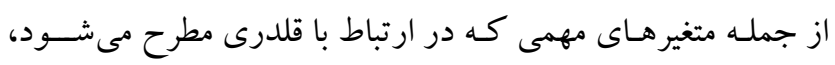

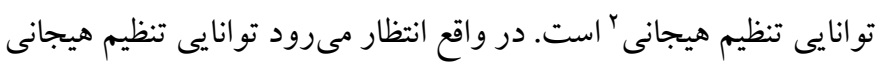

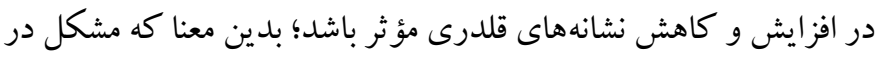

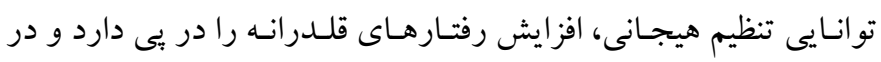

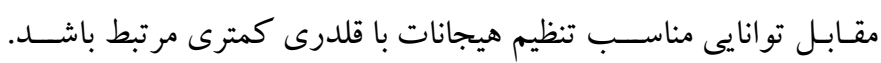
مطالعات مختلف، نقش واكنش هاى هيجانى و تنظيم هيجانى را در آغاز و نكهارى بسيارى از نشانهاى روانشناختى نشان مى دهند (Y) (Y). تنظيم

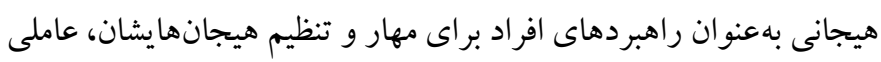

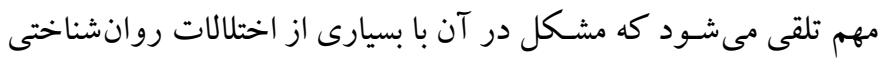

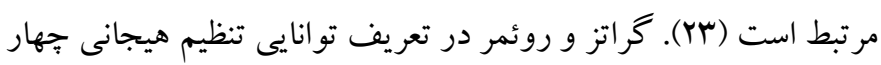

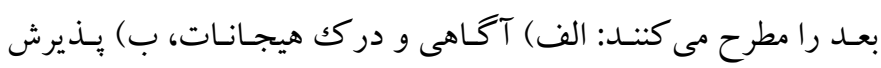

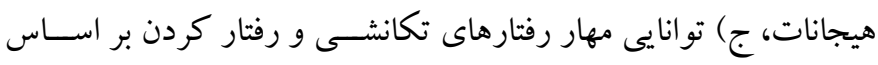

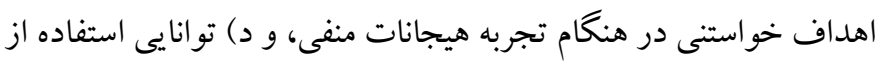

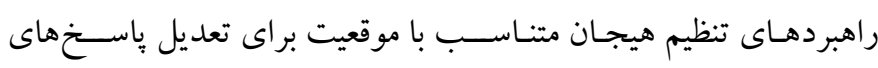

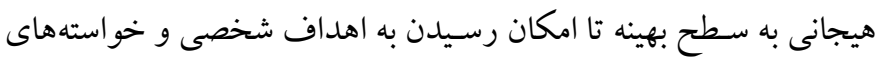

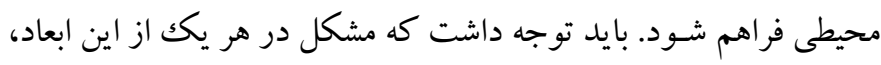

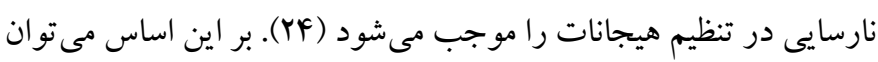

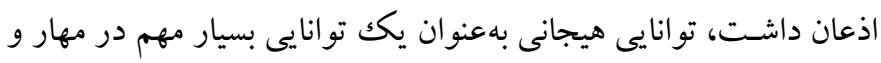

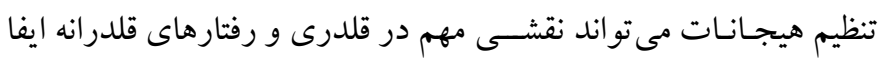

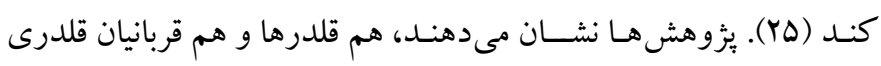
معمولاً از روش هاى مقابله و راهبردهاى تنظيم هيجانى ناكار آمد اسـتفاده

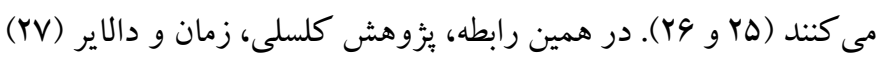

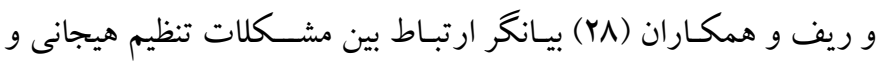

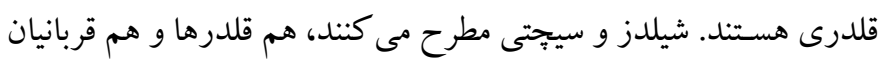

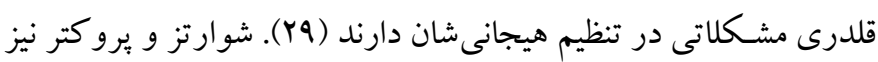
عنوان مى كنند، قربانى خشونت شدن با بيامدهاى اجتماعى منفى همجيون دهرن

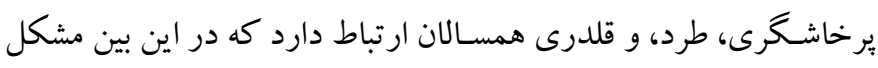

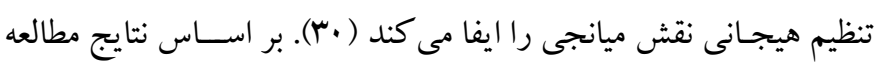


نقش مهمى را ايفـا مى كند (rN). در مجموع، منطبق با يافتهاى مطالعات

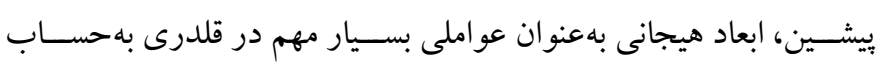

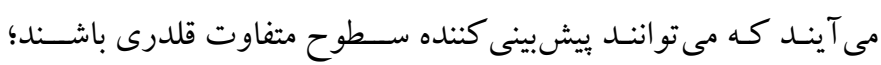

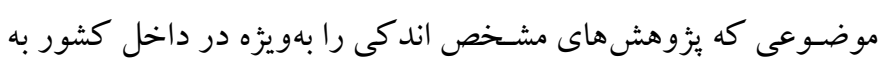

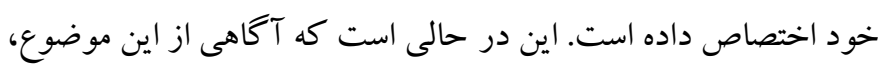

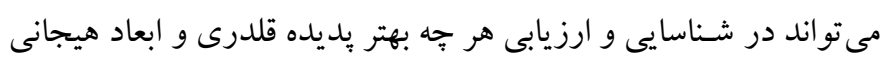
مر تبط با آن بسيار مفيد باشد.

در مجموع، مطالعه بِديده قلدرى بهعنوان موضوعى بيجِيده و گسترده

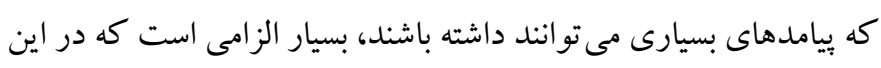
بين بررسـى رابطه قلدرى با متغيرهاى مهمى همجيون تنظيم هيجانى و

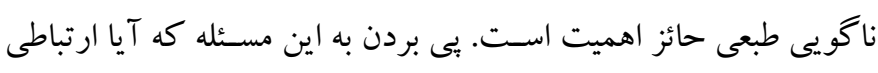

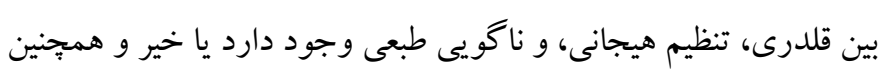

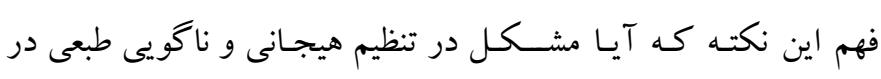

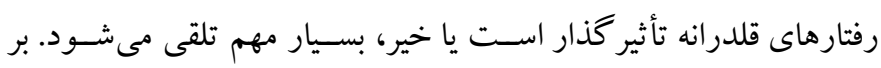

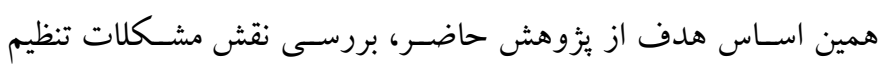
هيجانى و ناكويى طبعى در بيشبينى قلدرى است.

روش

الف) طرح يزوهش و شـــ كت كنند كان: طرح يزوهش توصسيفى و از

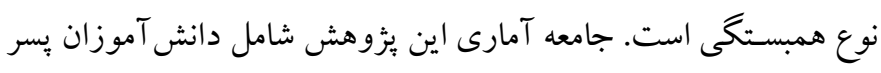

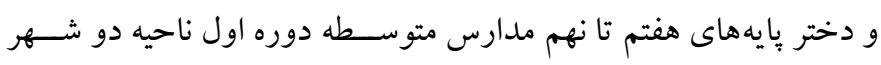

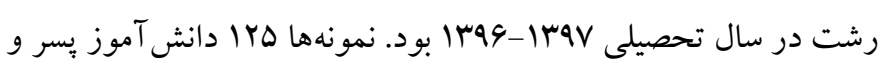

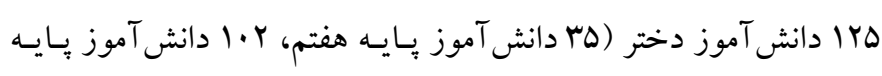

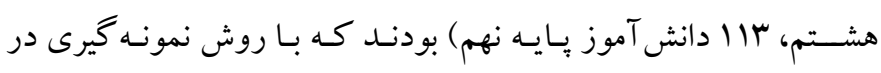

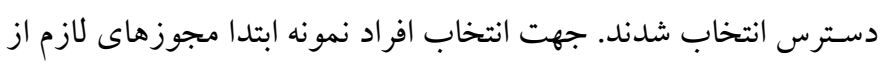

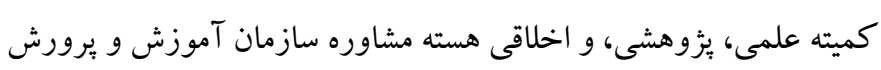

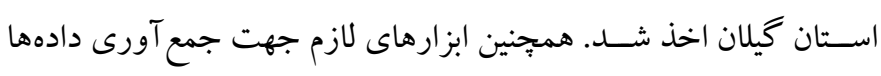

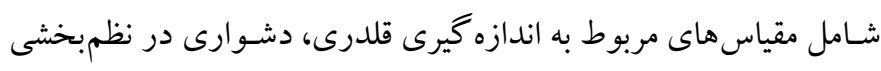

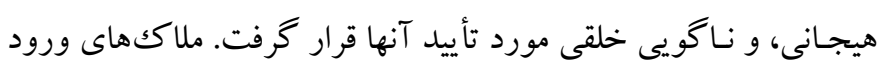

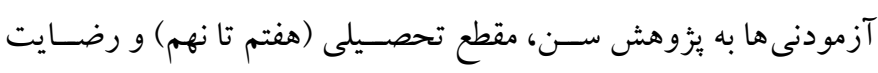

3. Cyber victimization
كارنر و هينتون، افراد قلدر و قربانيان قلدرى از مهارتهاى خود-تنظيمى هيجان' ضعيف ترى برخوردار هستند (آ).

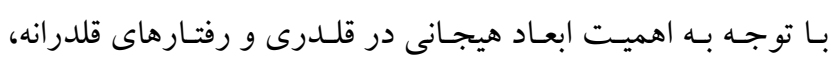
ناكويى طبعى متغير ديخرى اسـت كه انتظار مىرود با رفتارهاى قلدرانه

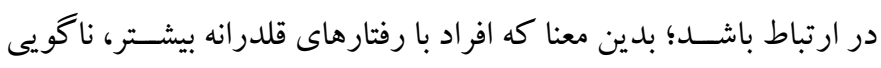

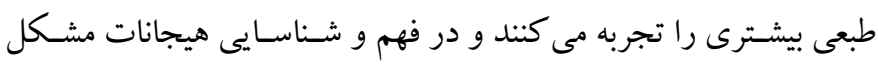

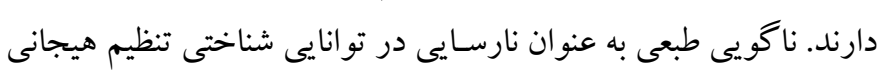

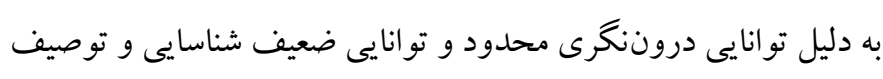

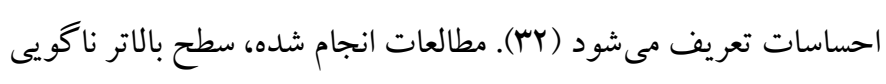

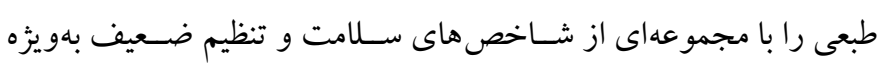

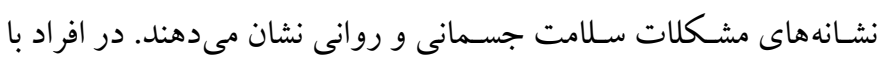
ناگويى طبعى در آكاهى هيجانى و تعاملات دراى مشكلات اساسى هستند

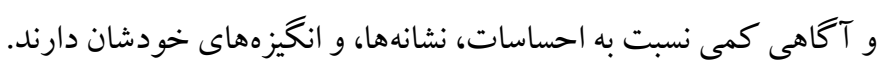

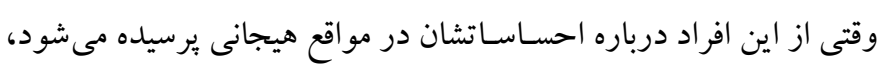

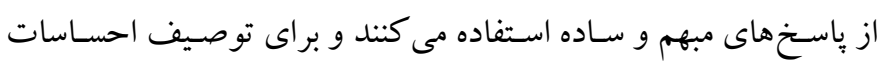

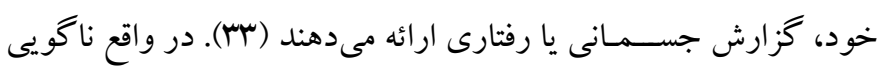

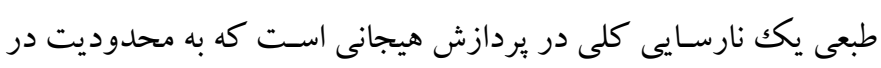

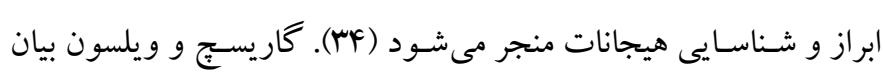

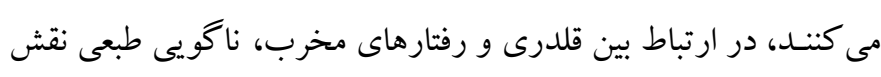

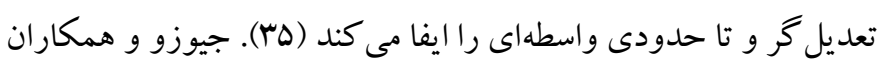
مطرح مى كنند، ناكويى طبعى در ارتباط قربانى قلدرى شـدن ون و نشانه هاى

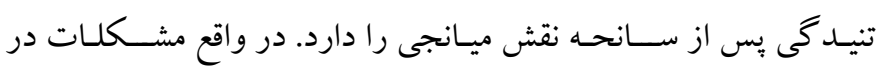

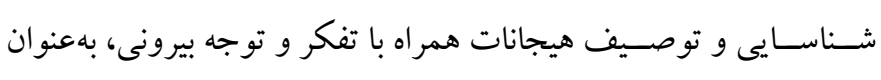

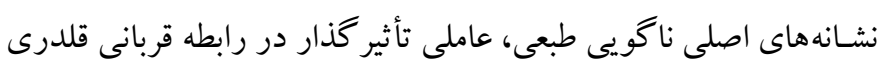

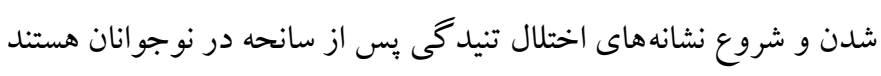

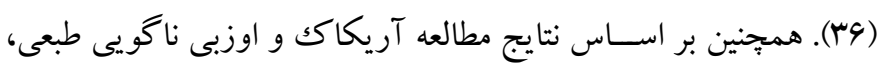

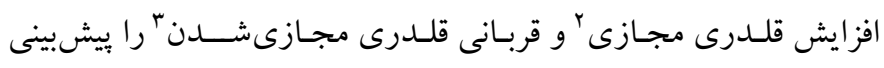

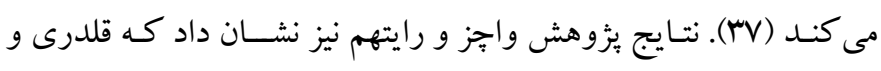

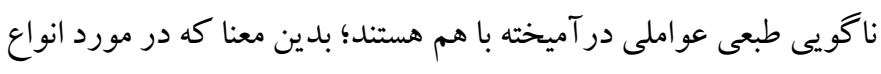

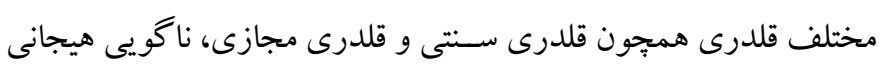

1. Emotion self-regulation

2. Cyber bullying 


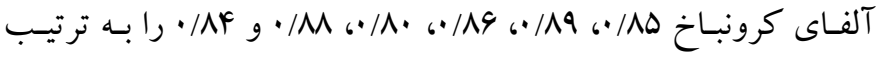
بر ايى عدم يذيرش ياسـخ هاى هيجانى، دشـوارى در انجام رفتار هدفمند،

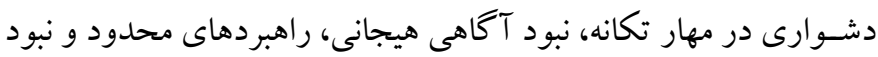

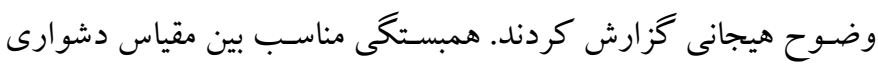

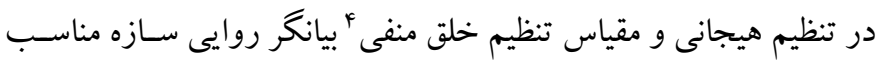

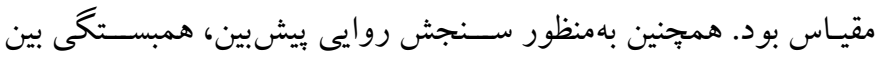

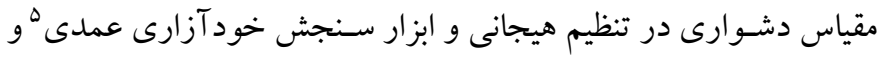

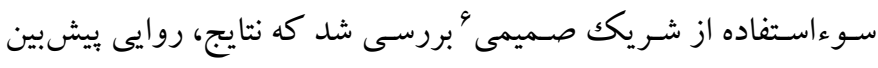

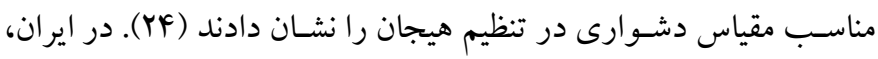

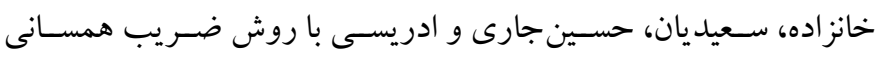

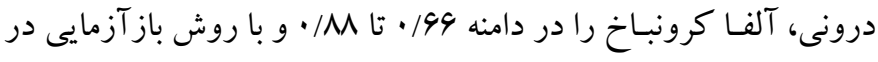

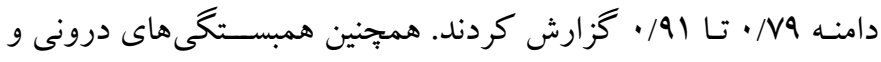

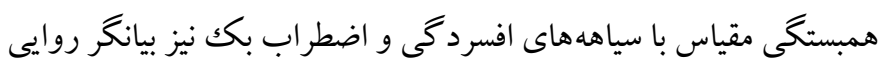

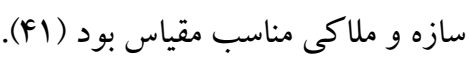

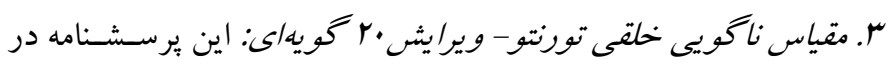

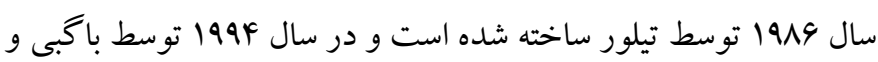

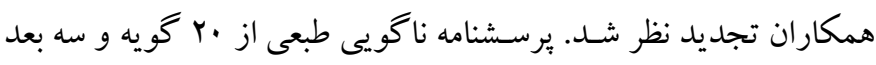

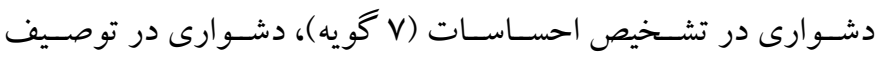
احسـاسـات (ه گويه)، و تفكر برونمدار (^ گويه) تشـكيل شــده اسـت.

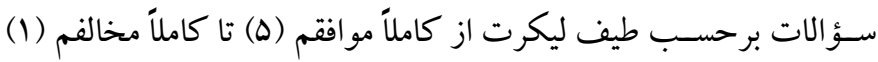

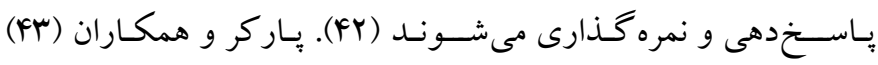

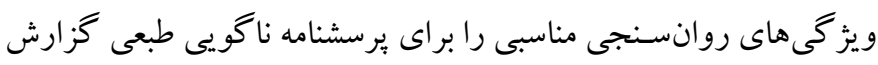

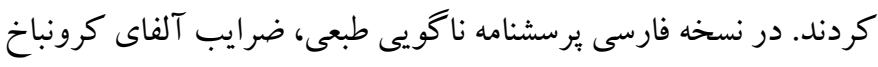

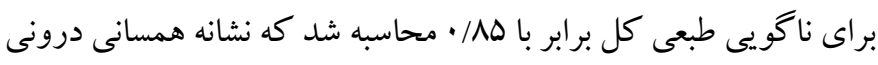

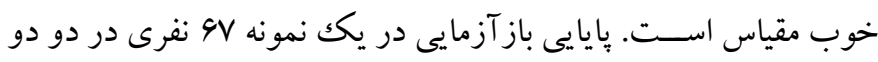

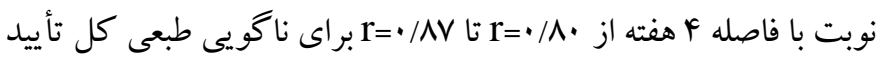

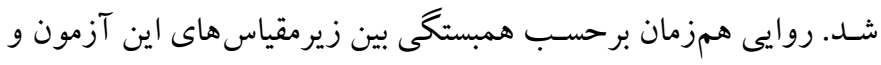

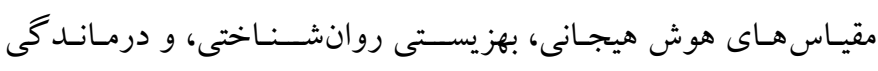

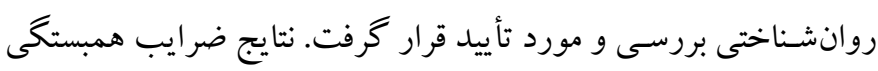

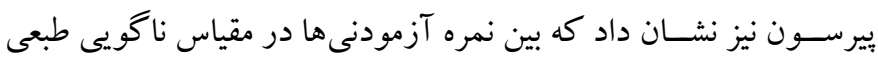

4. Negative mood regulation scale

5. Deliberate self-harm

6. Intimate partner abuse
دانش آموزان، رضــايت والدين، و مســئولين مدرســه بود و ملاككهاى

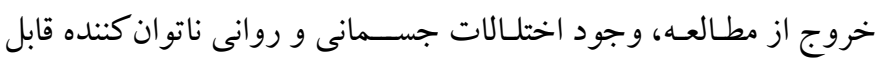

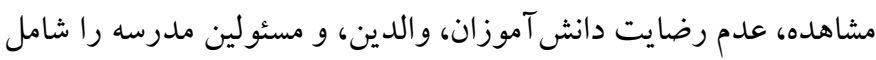

$$
\text { مى شلد. }
$$

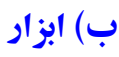

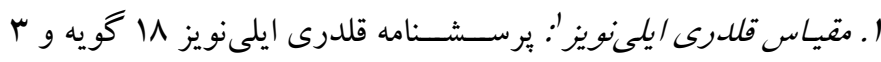
زيرمقياس قلدرى، زدوخورد، و قربانى را شـامل مىشـود كه بهصسورت

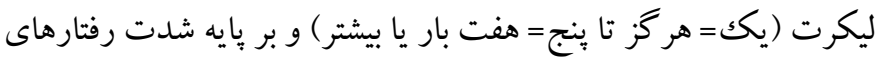

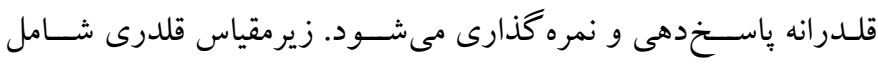

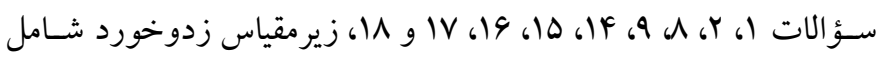

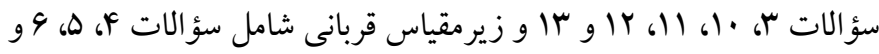

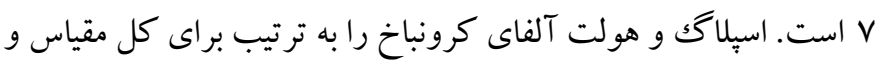

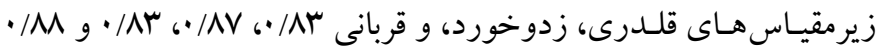

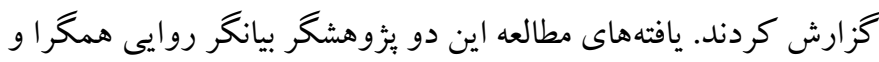
افتر اقى مناسب مقياس نيز بود. بر طبق نتايج به دست آمده، مقياس قلدرى ئرى

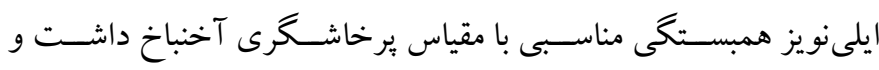

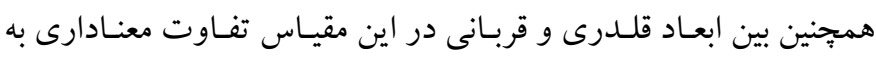

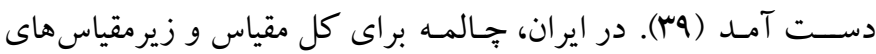

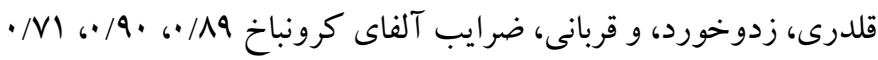

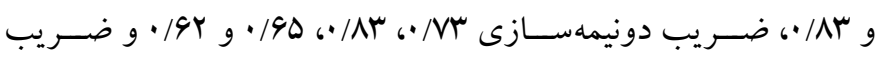

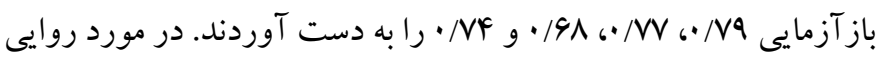
مقياس، جالمه با بررسـى ارتباط مقياس قلدرى ايلىنويز و يرســــــامه

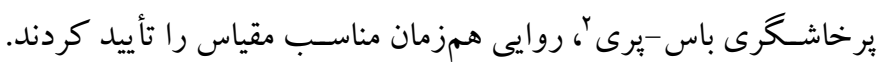

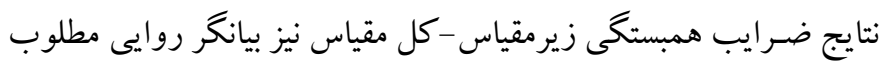

مقياس قلدرى ايلى نويز بود (F.).

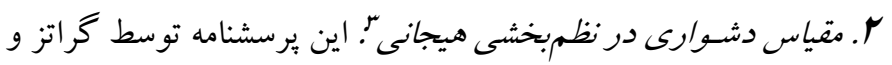
روئمر براى سـنجش ميزان دشـوارى در تنظيم هيجانى طراحى شده است

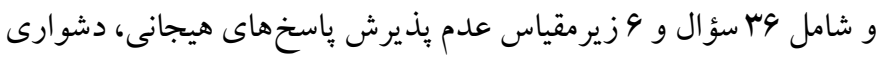

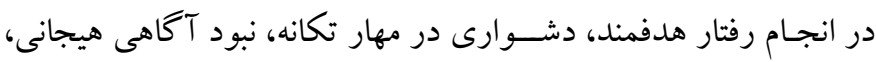

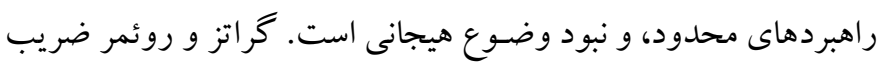

1. Illinois Bullying Scale (IBS)

2. Buss-Perry Aggression Questionnaire

3. Difficulties in emotional regulation scale (DERS) 
شــ كه اطلاعات حاصل از يُوهش بهصورت گُروهى مورد تحليل قرار

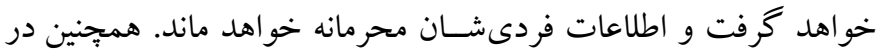

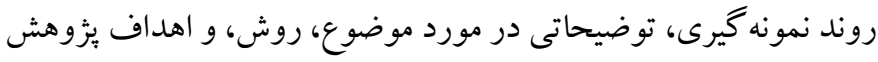

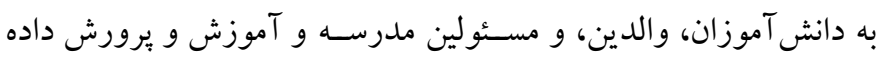

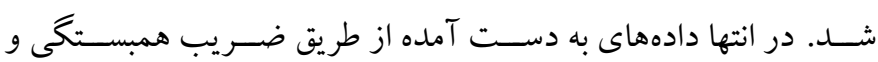
رگرسيون جند گانه مورد وارسى و تحليل قرار گر فتند.

\section{يافتهها}

در جدول ا شــاخصهاى توصـيفى متغيرهاى ثيزوهش اعم از كمينه،

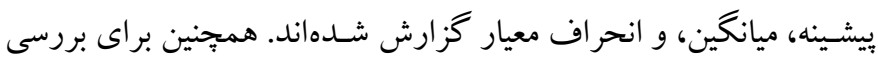

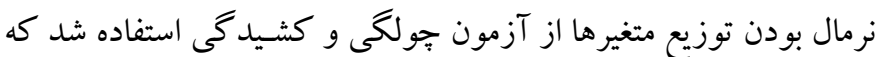
اين شاخص ها در جدول شماره ا گزارش شدند.

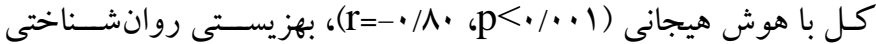

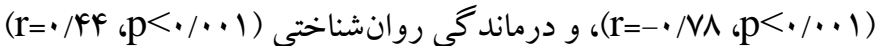
همبستخى معنادار وجود دارد (FF).

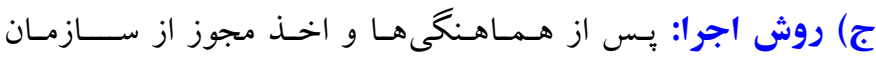

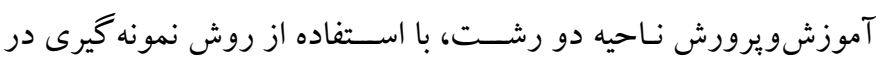
دسـترس، ••rD دانش آموز بِايههاى هفتم، هشتم، و نهم مدارس متوسطه

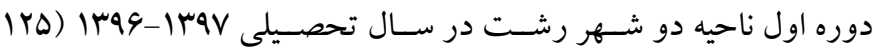

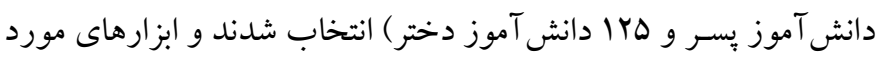

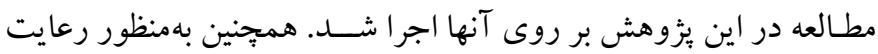

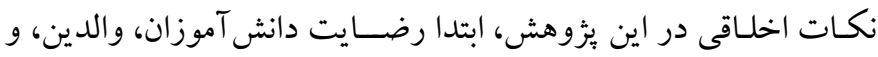
مسئولين مدرسه جلب شد و اين امكان به دانش آموزان داده شد تا در هر مرحله از يُزوهش كه تمايل داشتند، انصراف دهند و به آنها اطمينان داده

جدول 1: شاخصهاى توصيفى و نتايج بررسى نرمال بودن توزيع متغيرهاى يزوهش

\begin{tabular}{|c|c|c|c|c|c|c|}
\hline كشيدكى & جولَى & انحر اف معيار & ميانكين & بيشين & كمينه & متغير هاى ثئوهش \\
\hline I/AVI & $1 / 49$ & F/rT & $1 r / 94$ & $r$. & 9 & 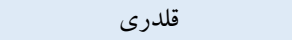 \\
\hline $1 / r 1$ & $1 / Y r$ & $r / I V$ & $\Lambda / Y \Lambda$ & $r$. & $\Delta$ & زدوخورد \\
\hline $1 / \cdot 9$ & $1 / 19$ & $r / I r$ & $\Delta / F F$ & if & F & قربانى \\
\hline $1 / \cdot$ & $\cdot / 4$. & $q / Y V$ & $1 r / 94$ & $r$. & 9 & عدم يذيرش ياسخهاى هيجانى \\
\hline$-\cdot / \Lambda F$ & $-\cdot / 1 \wedge$ & $F / v$. & $|r /|$. & rr & $\Delta$ & دشوارى در انجام رفتار هدفمند \\
\hline$-\cdot 191$ & $\cdot / r$ & $\Delta / / q$ & $\mid F / F T$ & Y4 & 9 & دشوارى در مهار تكانه \\
\hline$-\cdot / \Delta r$ & $-\cdot / \Delta \Delta$ & $9 / \mu_{1}$ & IN/YF & r. & 9 & نبود آكاهى هيجانى \\
\hline$-\cdot / \Lambda F$ & $\cdot / \cdot \vee$ & $9 / 91$ & $|N / 9|$ & rF & $\wedge$ & راهبردهاى محدود \\
\hline$-\cdot / T$ & $-\cdot / \mu V$ & $r / 9$. & IN/AV & ri & $\Delta$ & نبود وضوح هيجانى \\
\hline$-\cdot / \Delta \Lambda$ & $\cdot / \Lambda \Delta$ & 9/^9 & $1 \pi / 91$ & r & v & دشوارى در تشخيص احساسات \\
\hline$-\cdot / 9 r$ & $\cdot / \cdot \wedge$ & $r / \cdot r$ & $11 / 94$ & ri & $\Delta$ & دشوارى در توصيف احساسات \\
\hline $1 / r V$ & $-1 / \mu V$ & $\Delta / A r$ & rI/A9 & $r$. & $\wedge$ & تفكربرونمدار \\
\hline
\end{tabular}

هيجانى و ناكويى طبعى و خرده مؤلفهاى آنها بر قلدرى دانش آموزان

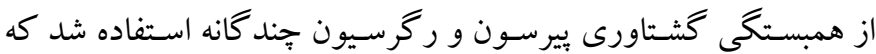
نتايج آن در جدول r ارائه شده است.
مقدار جولكى و كشـيد گى مشاهده شده براى تمامى متغير ها در بازه

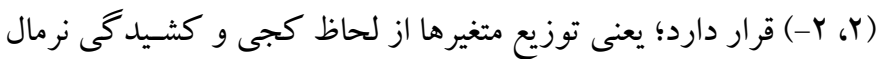

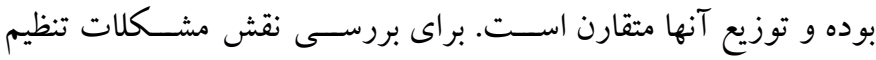


جدول r: ماتريس همبستغى رابطه بين قلدرى، مشكلات تنظيم هيجانى و ناتويى طبعى

\begin{tabular}{|c|c|c|c|c|c|c|c|c|c|c|c|c|}
\hline ir & 11 & $1 \cdot$ & 9 & $\wedge$ & $\checkmark$ & 7 & 0 & $\varepsilon$ & $r$ & r & 1 & متغير هاى ثئوهش \\
\hline & & & & & & & & & & & 1 & ا 1. قلدرى \\
\hline & & & & & & & & & & 1 & ***.*191 & r. ا. زدوخورد \\
\hline & & & & & & & & & 1 &.$/ 11$ & $* / / r$ & 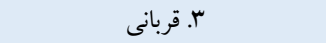 \\
\hline & & & & & & & & 1 & 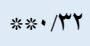 & 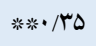 & **** $\cdot|4|$ & F. عدم קذيرش باسخهاى هيجانى \\
\hline & & & & & & & 1 & *** $6 / 91$ & $* * / r q$ & 絭菂・/r & ***/rq & هـ. دشوارى در انجام رفتار هدفمند \\
\hline & & & & & & 1 & $* * / A r$ & $* * / V^{4}$ & 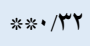 & 䄅标・/rV & $* * / 4 q$ & 9. دشوارى در مهار تكانه \\
\hline & & & & & 1 & $* * / \Delta F$ & ***. 19. & *** $* / f F$ & $* / 19$ & 䄅当. $/$ Y D & ***/19 & V. نبود آكاهى هيجانى \\
\hline & & & & 1 & $* * / \Delta 9$ & $* * / V q$ & $* * / V 9$ & ***/V9 & $* * / r q$ & ***/T4 & 䄅粈/ & 1 ر راهبردهاى محدود \\
\hline & & & 1 & 类漛. $/ 94$ & $* * / \Delta 9$ & 䄅光. $/ \Delta \Lambda$ & ***. & $\approx * / \Delta r$ & 米㫧 & 䄅光. $/ \& \Delta$ & 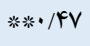 & 9. نبود وضوح هيجانى \\
\hline & & 1 & 㭗㭗./W & 类漛./Ir & $\cdot / 1 r$ & ***. & ***/rq & ***/19 & 米米. $/$. & .1 .9 & 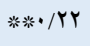 & • ا دشوارى در تشخيص احساسات \\
\hline & 1 & $* * 19 \Lambda$ & 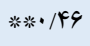 & ***. & $* * / \mu r$ & ***/rF & $* * / \mu F$ & *** $/$ r. & $* * / Y I$ & *** $/ I V$ & 粗㭗。/ & 11. دشوارى در توصيف احساسات \\
\hline & 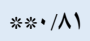 & 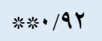 & 䄅西. $/ A V$ & 䄅当. $/ 01$ & ****/91 & 类䄅・/Dr & ***\% & 米籿/ 4 . & 米米, & 䄅然, $/$ I & 䄅西. $/ \Gamma V$ & ז ا. تفكر برونمدار \\
\hline
\end{tabular}

هيجـانى و ناكويى طبعى را نشــان مىدهد. در اين جدول مقادير F، R،

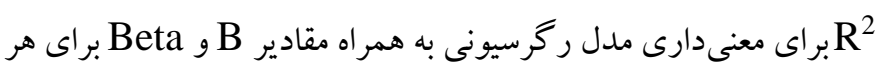

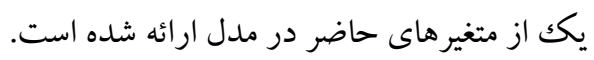

جدول ب نتايج به دسـت آمده از ماتريس همبسـتخى را نشان مىدهد

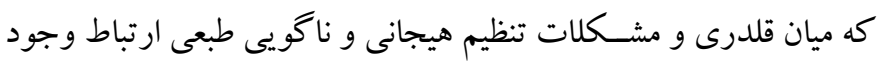

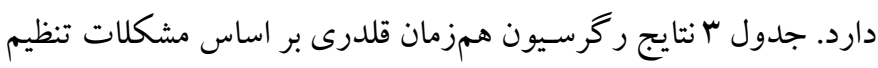

جدول ب: نتايج تحليل ركرسيون همزمان براى بيشيينى قلدرى بر اساس مشكلات تنظيم هيجانى و ناتويى طبعى

\begin{tabular}{|c|c|c|c|c|c|c|c|c|}
\hline $\mathbf{R}^{2}$ & $\mathbf{R}$ & سطح معنادارى & $\mathbf{F}$ & ميانكين مجذورات & درجه آزادى & مجموع مجذورات & مل & \\
\hline \multirow{3}{*}{ - /FGF } & & & & rrq/FG & 9 & $r \mid \Delta \Delta / 19$ & ركرسيون & \\
\hline & .1911 & $\mathrm{P}<\cdot / \cdots 1$ & $r r / \cdot F$ & $1 \cdot / 49$ & TF. & YFqF/ID & باقى مانده & 1 \\
\hline & & & & & rFq & FqFq/TI & كل & \\
\hline
\end{tabular}

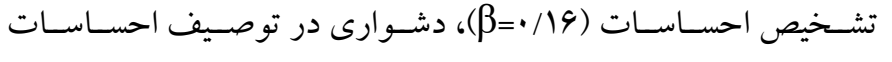

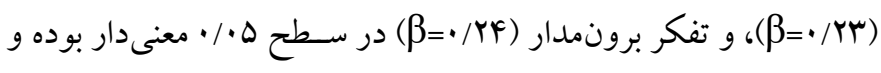
قادر به بيشبينى قلدرى هستند.

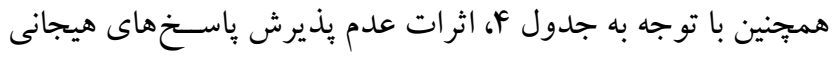

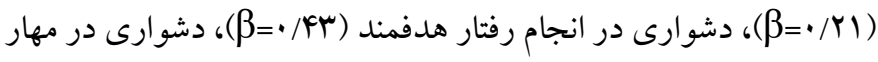

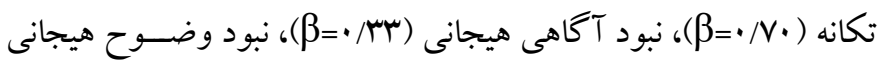
( )

جدول ع: نتايج ضرايب مربوط به ركرسيون جند انانه همزمان براى بيشينى قلدرى بر اساس مشكلات تنظيم هيجانى و ناكويى طبي

\begin{tabular}{|c|c|c|c|c|c|}
\hline سطح معنادارى & $\mathbf{t}$ & ضرايب استاندارد & & ضرايب غيراستاندارد & th \\
\hline & & Beta & خطاى استاندارد & B & \\
\hline.$\cdots 1$ & $9 / 490$ & - & - /AFV & $\Delta / r \cdot V$ & مقدار ثابت \\
\hline$\% \cdots \wedge$ & $r / 90 \Lambda$ & $\cdot / r 11$ & $\cdot / \cdot \Delta \Delta$ & ./1FG & عدم يذيرش پياسخهاى هيجانى \\
\hline.$\cdots 1$ & F/FAT & . & $\cdot / \cdot M$ & $\cdot / \mathrm{mav}$ & دشوارى در انجام رفتار هدفمند \\
\hline.$\cdots 1$ & $V /$ IFq & $\cdot / v \cdot 1$ & $\cdot / \cdot \vee \wedge$ & .1091 & دشوارى در مهار تكانه \\
\hline$\%$ & $F / \Delta / 9$ & 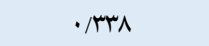 & $\cdot / \cdot \Delta 1$ & . TrA & نبود آكاهى هيجانى \\
\hline
\end{tabular}




\begin{tabular}{|c|c|c|c|c|c|}
\hline$\cdot / \cdot \mathrm{YA}$ & r/Y/Q & $\cdot / / 10$ & .1 .91 & ./IMF & راهبردهاى محدود \\
\hline$\cdot / \cdot 1$ & $F / N I$. & $\cdot /$ TYV & $\cdot / \cdot \wedge r$ & . rar & نبود وضوح هيجانى \\
\hline$\cdot / \cdot F r$ & $r / F F$ &.$/ 191$ & $\cdot / \cdot \Delta$ &.$/ 1 \cdot 1$ & دشوارى در تشخيص احساسات \\
\hline $.1 \cdot 10$ & T/FFD & $\cdot /$ rMF & $. / 1 . r$ & $\cdot / T \Delta 1$ & دشوارى در توصيف احساسات \\
\hline$\cdot / \cdot 1$ & r/91Y & - IYFD & $\% \cdot v$ & . IAr & تفكربرونمدار \\
\hline
\end{tabular}

مشكلات در يذيرش باسخ هاى هيجانى و رفتارهاى هدفمند، دشوارى در

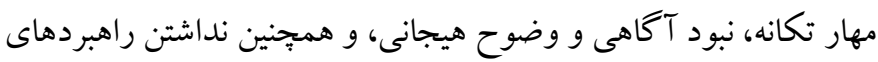

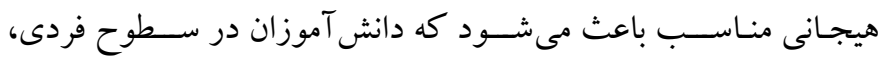
بينفردى، و جمعى با مشكلات بيشترى مواجه شوند و قادر به حل آن از ماز

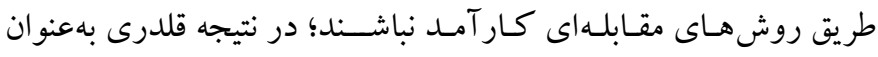

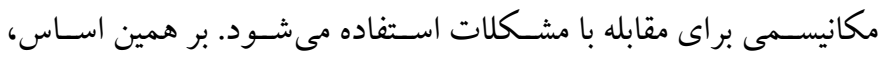

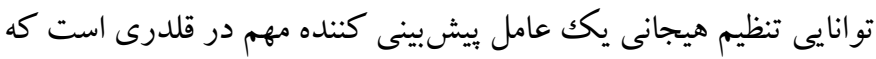
سطوح يايين اين توانايى مى تواند سطوح بالاى قلدرى را ييشبينى كند.

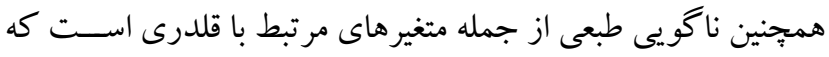
مى تواند نقش بسز ايى در افزايش و كاهش رفتارهاى قلدرانه داشته باشد.

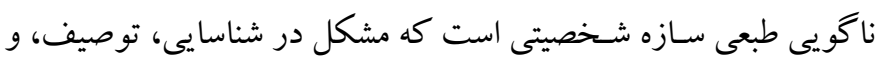
سبكك تفكر بيرونى را شـامل مى شـود كه نشـانكر نارسـايى در فرايند يردازش شـناختى تجارب هيجانى اسـت. رابطه ناكويى طبعى با جنبه هاى

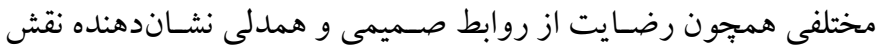

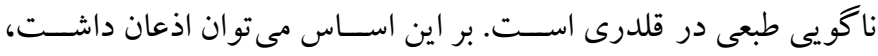

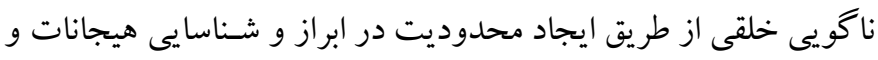

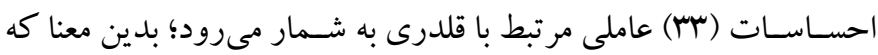

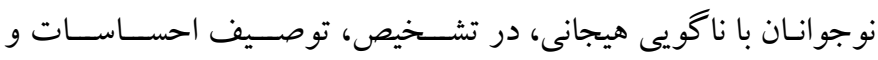

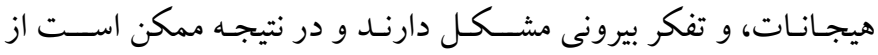
راهبردهاى ديخرى همجيجون برخاشــرى و قلدرى بهره گيرند. در همين

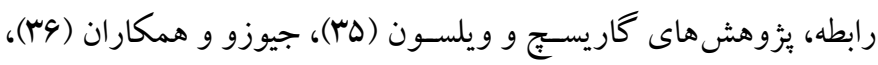

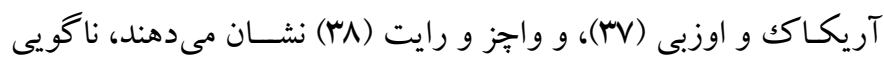
طبعى عـاملى مؤثر در قلـدرى نوجو انـان اســت. نتايج مطالعه ييشرو نيز

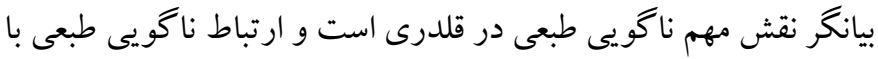

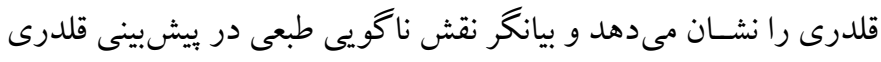

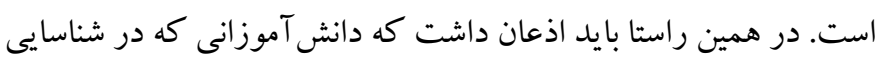
و توصيف هيجانات مشكل دارند قادر به ارزيابى درست هيجانات خود و

\section{بحث و نتيجه تيرى}

يزروهش حاضـر به منظور بررسـى رابطه قلدرى، توانايى تنظيم هيجانى و

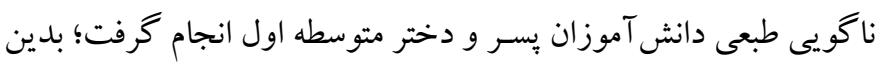

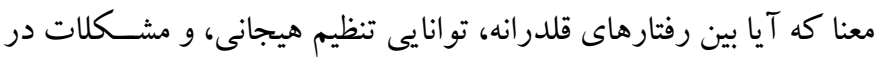

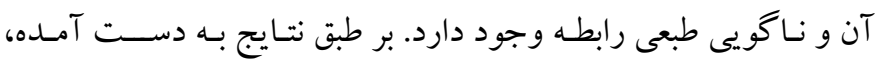

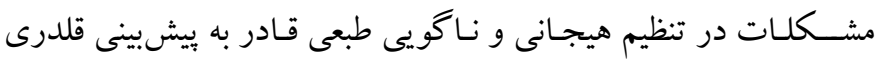

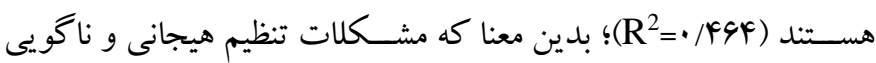
طبعى بـا قلـدرى دانش آموزان مرتبط بوده و مى تو اننـــ بيشبينى كنتـده قلدرى آنها باشند.

توانسايى تنظيم هيجانى بهعنوان عاملى مؤثر در قلدرى، مى تواند نقش

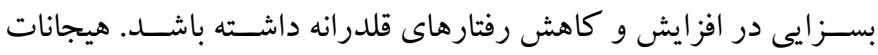

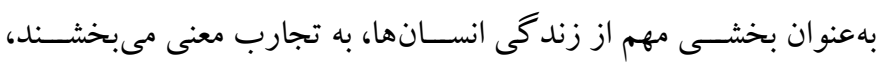

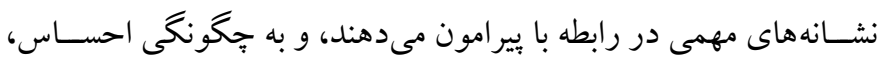
تفكر و عمل شـكل مىدهند كه در اين بين توانايى تنظيم هيجانات بسيار

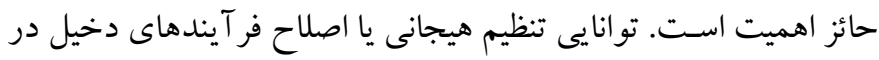

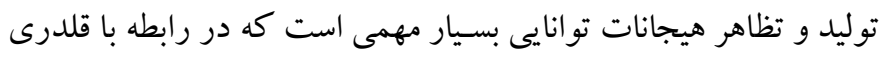

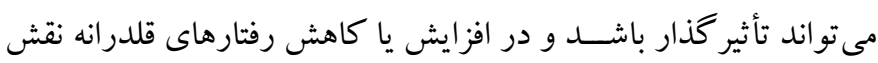

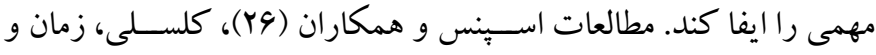

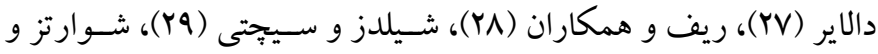

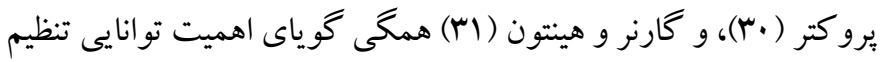

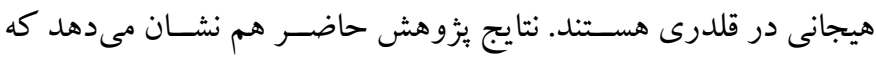

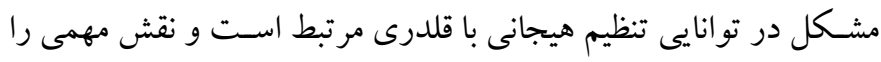

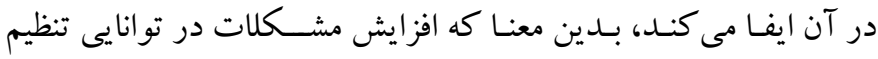

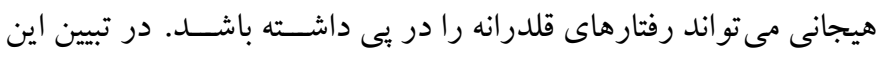

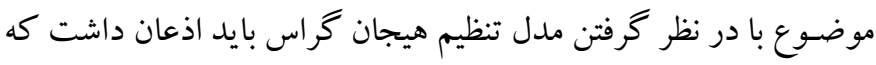

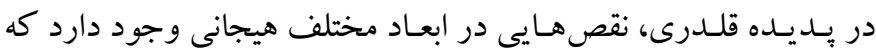
منجر بـه قلدرى، زد و خود، و قربانى قلدرى شـــن مىشـــود. در واقع، 
بيشـنهاد مىشـود، بزوهش هاى ديخر با بررسى متغيرهاى ذكر شده و رفع

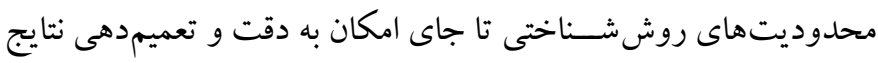

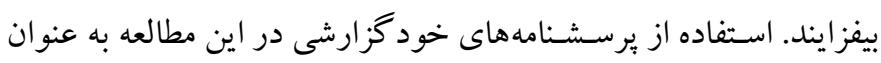

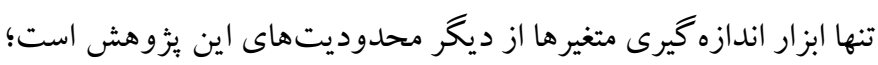

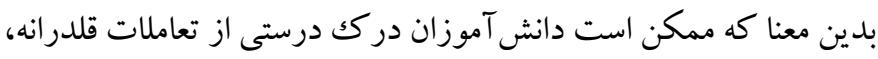

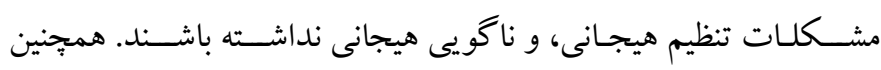

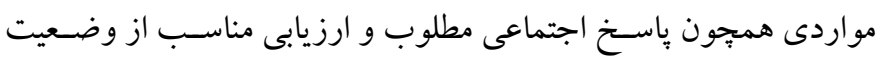

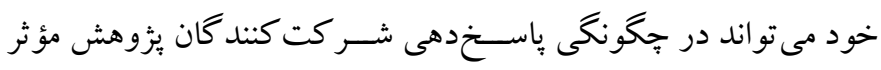

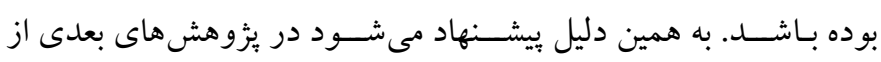

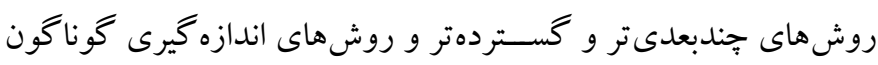

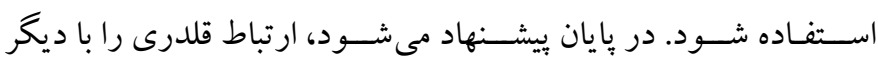

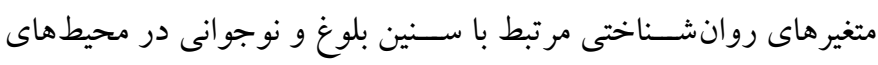
متفاوت از محيط تحصيل نيز مورد بررسى قرار گيرد.

تشـكر و قدردانى: اين مطالعه بهصورت مستقل اجرا شـده اسـت و حاصـل

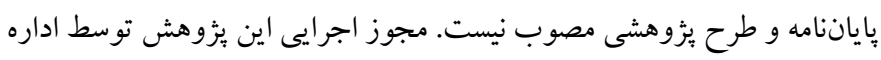

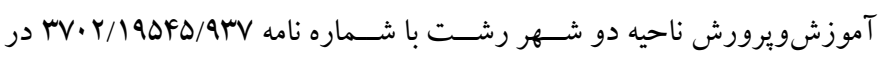

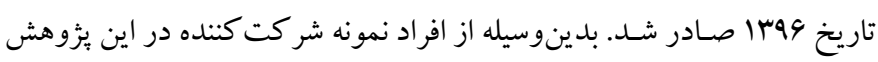

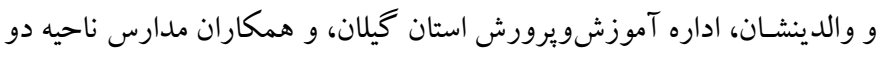

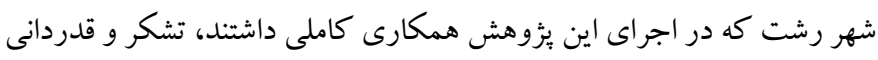
مىشود. تضـاد منافع: اين بزوهش براى نويسـند كان هيج گُونه تضـاد منافعى به دنبال نداشته است.
ديخر ان نيسـتند كه در نتيجه آن سـوءبرداشـتها و تحريفات هيجانى و

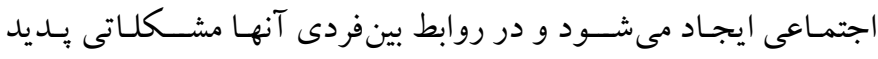

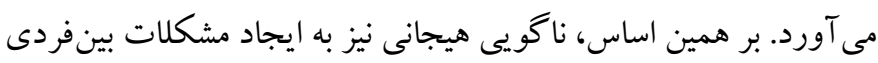

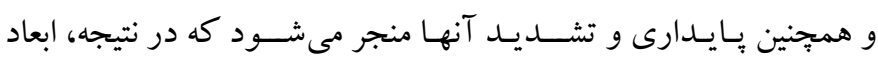
مختلف قلدرى شـامل قلدرى، زدوخورد، و قربانى قلدرى شـــدن اتفاق مى افتد.

در مجموع نتايج ئزوهش حاضر نشان مىدهند، ابعاد هيجانى همجون

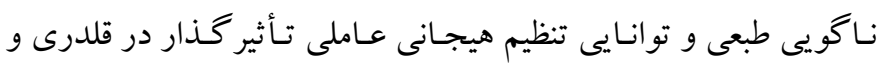

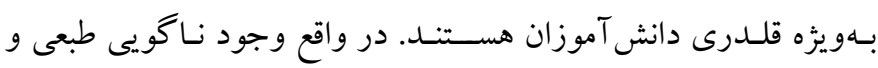

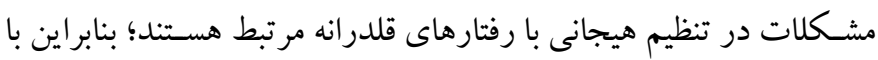

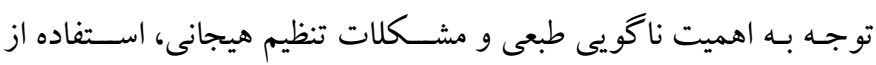

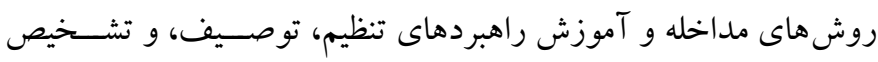

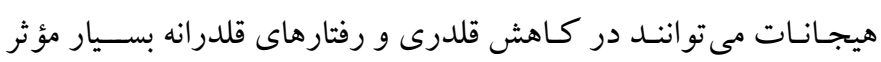
باشند.

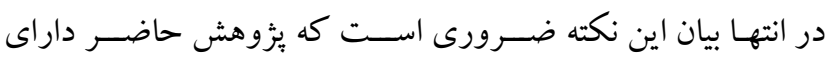
محدوديت هايى نيز اسـت. جامعه آمارى اين بثزوهش، كود كان سار تا هان 10

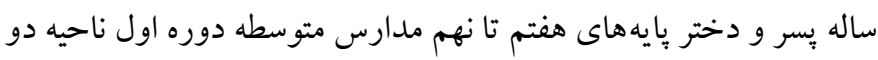

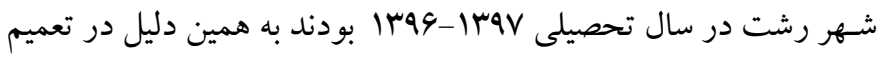
نتايج به سـاير گروههاى سنى و تحصيلى بايد جانب احتياط رعايت شود ده.

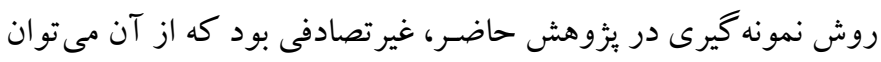

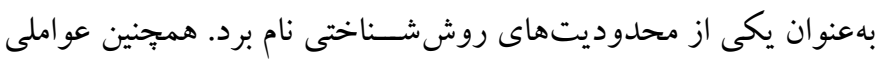

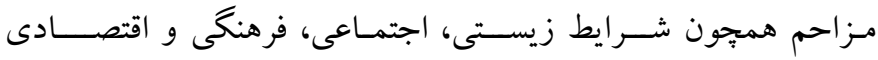

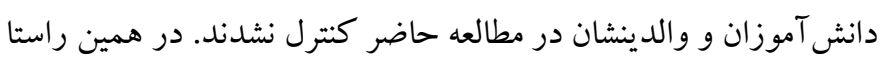




\section{References}

1. Hymel S, Swearer SM. Four decades of research on school bullying: an introduction. Am Psychol. 2015; 70(4): 293-299. [Link]

2. Rettew DC, Pawlowski S. Bullying. Child Adolesc Psychiatr Clin N Am. 2016; 25(2): 235-242. [Link]

3. Walters GD, Espelage DL. From victim to victimizer: Hostility, anger, and depression as mediators of the bullying victimization-bullying perpetration association. J Sch Psychol. 2018; 68:73-83. [Link]

4. Rigby K, Smith PK. Is school bullying really on the rise? Soc Psychol Educ. 2011; 14(4): 441-455. [Link]

5. Salmon S, Turner S, Taillieu T, Fortier J, Afifi TO. Bullying victimization experiences among middle and high school adolescents: Traditional bullying, discriminatory harassment, and cybervictimization.J Adolesc.2018; 63: 29-40. [Link]

6. Volk AA, Dane AV, Marini ZA. What is bullying? A theoretical redefinition. Dev Rev. 2014; 34(4): 327343. [Link]

7. Elgar FJ, McKinnon B, Walsh SD, Freeman J, D Donnelly $\mathrm{P}$, de Matos MG, et al. Structural determinants of youth bullying and fighting in 79 countries. J Adolesc Health. 2015; 57(6): 643-650. [Link]

8. Srabstein JC, Leventhal BL. Prevention of bullyingrelated morbidity and mortality: a call for public health policies. Bull World Health Organ. 2010; 88(6): 403. [Link]

9. Bjereld Y, Daneback K, Petzold M. Differences in prevalence of bullying victimization between native and immigrant children in the Nordic countries: a parent-reported serial cross-sectional study. Child Care Health Dev. 2015; 41(4): 593-599. [Link]

10. Fleming LC, Jacobsen KH. Bullying among middleschool students in low and middle income countries. Health Promot Int. 2010; 25(1): 73-84. [Link]

11. Kazarian SS, Ammar J. School bullying in the Arab world: a review. The Arab Journal of Psychiatry. 2013; 44(473): 1-18. [Link]

12. Scott JG, Moore SE, Sly PD, Norman RE. Bullying in children and adolescents: a modifiable risk factor for mental illness.Aust N Z J Psychiatry.2014; 48(3): 209212. [Link]

13. Klomek AB, Sourander A, Elonheimo H. Bullying by peers in childhood and effects on psychopathology, suicidality, and criminality in adulthood. Lancet Psychiatry. 2015; 2(10): 930-941. [Link]

14. Volk AA, Schiralli K, Xia X, Zhao J, Dane AV. Adolescent bullying and personality: A cross-cultural approach. Pers Individ Dif. 2018; 125: 126-132. [Link]

15. Kaltiala-Heino R., Fröjd S. Correlation between bullying and clinical depression in adolescent patients. Adolesc Health Med Ther.2011; 2: 37-44. [Link]

16. McCabe RE, Antony MM, Summerfeldt LJ, Liss A, Swinson RP. Preliminary examination of the relationship between anxiety disorders in adults and self-reported history of teasing or bullying experiences. Cogn Behav Ther. 2003; 32(4): 187-193. [Link]

17. Thomas HJ, Chan GCK, Scott JG, Connor JP, Kelly $\mathrm{AB}$, Williams J. Association of different forms of bullying victimisation with adolescents' psychological distress and reduced emotional wellbeing.Aust N Z J Psychiatry. 2016; 50(4): 371379. [Link]

18. Chester KL, Spencer NH, Whiting L, Brooks FM. Association between experiencing relational bullying and adolescent health-related quality of life. J Sch Health. 2017; 87(11): 865-872. [Link]

19. Modin B, Låftman SB, Östberg V. Bullying in context: An analysis of psychosomatic complaints among adolescents in Stockholm. J Sch Violence. 2015; 14(4): 382-404. [Link]

20. McMahon EM, Reulbach U, Keeley H, Perry IJ, Arensman E. Reprint of: bullying victimization, selfharm and associated factors in Irish adolescent boys. Soc Sci Med. 2012; 74(4): 490-497. [Link]

21. Dukes RL, Stein JA, Zane JI. Gender differences in the relative impact of physical and relational bullying on adolescent injury and weapon carrying.J Sch Psychol. 2010; 48(6): 511-532. [Link]

22. Jazaieri H, Morrison AS, Goldin PR, Gross JJ. Emotion regulation: affective, cognitive, and social consequences. Curr Psychiatry Rep. 2015; 17:531. [Link]

23. Gross JJ, Thompson RA. Emotion regulation: conceptual foundations. In: Gross JJ, editor. Handbook of emotion regulation. New York, NY, US: The Guilford Press; 2007, pp: 3-24. [Link]

24. Gratz KL, Roemer L. Multidimensional assessment of emotion regulation and dysregulation: development, factor structure, and initial validation of the difficulties in emotion regulation scale. $\mathbf{J}$ Psychopathol Behav Assess. 2004; 26(1): 41-54. [Link]

25. Lang J. The efficacy of emotional intelligence training for the emotion regulation of bullying students: A randomized controlled trial. NeuroQuantology. 2018; 16(2): 83-88. [Link] 
26. Spence SH, De Young A, Toon C, Bond S. Longitudinal examination of the associations between emotional dysregulation, coping responses to peer provocation, and victimization in children. Aust $\mathbf{J}$ Psychol. 2009; 61(3): 145-155. [Link]

27. Kelsey C, Zeman J, Dallaire D. Emotion correlates of bullies, victims, and bully-victims in African American children. J Black Psychol. 2017; 43(7): 688713. [Link]

28. Rieffe C, Camodeca M, Pouw LBC, Lange AMC, Stockmann L. Don't anger me! Bullying, victimization, and emotion dysregulation in young adolescents with ASD. Eur J Dev Psychol. 2012; 9(3): 351-370. [Link]

29. ShieldsA, Cicchetti D. Parental maltreatment and emotion dysregulation as risk factors for bullying and victimization in middle childhood. J Clin Child Adolesc Psychol. 2001; 30(3): 349-363. [Link]

30. Schwartz D, Proctor LJ. Community violence exposure and children's social adjustment in the school peer group: The mediating roles of emotion regulation and social cognition. $\mathrm{J}$ Consult Clin Psychol. 2000; 68(4): 670-683. [Link]

31. Garner PW, Hinton TS. Emotional display rules and emotion self-regulation: Associations with bullying and victimization in community-based after school programs. J Community Appl Soc Psychol. 2010; 20(6): 480-496. [Link]

32. Ziadni MS, Jasinski MJ, Labouvie-Vief G, Lumley MA. Alexithymia, defenses, and ego strength: crosssectional and longitudinal relationships with psychological well-being and depression. J Happiness Stud. 2017; 18(6): 1799-1813. [Link]

33. Lumley MA, Neely LC, Burger AJ. The assessment of alexithymia in medical settings: implications for understanding and treating health problems. J Pers Assess. 2007; 89(3): 230-246. [Link]

34. Lane RD, Sechrest L, Riedel R, Shapiro DE, Kaszniak AW. Pervasive emotion recognition deficit common to alexithymia and the repressive coping style. Psychosom Med. 2000; 62(4): 492-501. [Link]
35. Garisch JA, Wilson MS. Vulnerabilities to deliberate self-harm among adolescents: the role of alexithymia and victimization. Br J Clin Psychol. 2010; 49(Pt 2): 151-162. [Link]

36. Guzzo G, Pace U, Lo Cascio V, Craparo G, Schimmenti A. Bullying victimization, post-traumatic symptoms, and the mediating role of alexithymia. Child Indic Res. 2014; 7(1): 141-153. [Link]

37. Aricak OT, Ozbay A. Investigation of the relationship between cyber bullying, cyber victimization, and alexithymia and anger expression styles among adolescents. Comput Human Behav.2016; 55:278285. [Link]

38. Wachs S, Wright MF. Bullying and alexithymia: Are there differences between traditional, cyber, combined bullies, and nonbullies in reading their own emotions?.Crim Behav Ment Health. 2018; 28(5): 409-413. [Link]

39. Espelage DL, Holt M. Bullying and victimization during early adolescence. Journal of Emotional Abuse. 2001; 2(2-3): 123-142. [Link]

40. Chalmeh R. Psychometrics Properties of the Illinois bullying scale (IBS) in Iranian students: validity, reliability and factor structure.Journal of Psychological Models and Methods. 2014; 3(11): 3952. [Persian]. [Link]

41. Khanzadeh M, Saeediyan M, Hosseinchari M, Edrissi F. Factor structure and psychometric properties of difficulties in emotional regulation scale. International Journal of Behavioral Sciences. 2012; 6(1): 87-96. [Persian]. [Link]

42. Bagby RM, Taylor GJ, Parker JD. The twenty-item Toronto alexithymia scale-ii.Convergent, discriminant, and concurrent validity. J Psychosom Res. 1994; 38(1): 33-40. [Link]

43. Parker JDA, Taylor GJ, Bagby RM. The relationship between emotional intelligence and alexithymia. Pers Individ Dif. 2001; 30(1): 107-115. [Link]

44. Besharat MA. Reliability and factorial validity of a Farsi version of the 20-item Toronto Alexithymia Scale with a sample of Iranian students. Psychol Rep. 2007; 101(1): 209-220. [Link] 